\title{
AKTIVITAS ANTIBAKTERI EKSTRAK ETANOL DAUN PANDAN WANGI (Pandanus amaryfolius) TERHADAP Staphylococcus aureus
}

\author{
Elza Rizkia Utami ${ }^{1}$, Yunilda Rosa ${ }^{2} *$ \\ 1,2. Program Studi S1 Farmasi STIK Siti Khadijah Palembang \\ Elza.riskia@gmail.com \\ Email Coauthor: yunildarosa2018@gmail.com
}

\begin{abstract}
ABSTRAK
Pandan wangi (Pandanus amaryllifolius) yang lazim digunakan sebagai pewangi dan pewarna makanan ternyata berpotensi memiliki aktivitas antibakteri. Bakteri Staphylococcus aureus merupakan bakteri yang dapat menyebabkan infeksi.Tujuan penelitian ini adalah untuk mengetahui aktivitas daun pandan wangi sebagai antibakteri Staphylococcus aureus, dengan mengetahui Konsentrasi Hambat Minimum (KHM) dan Konsentrasi Bunuh Minimum (KBM) serta untuk mengetahui senyawa kimia apa saja yang terkandung dalam daun pandan wangi. Ekstrak etanol daun pandan wangi diperoleh melalui metode maserasi menggunakan pelarut alkohol $70 \%$. Penelitian ini merupakan penelitian ekperimental dengan menggunakan post test only control group design, dengan menggunakan metode dilusi. Hasil penelitian menujukan bahwa nilai KHM pada konsentrasi $40 \%$ sudah mampu menghambat pertumbuhan bakteri staphylococcus aureus. Konsentrasi Bunuh Minimum (KBM) ekstrak daun pandan wangi pada bakteri staphyloccocus aureus wangi belum dapat ditentukan nilainya karena pada konsentrasi tertinggi 60\% masih terdapat pertumbuhan koloni rata-rata sebanyak 27 koloni.

Kata kunci : Daun Pandan wangi (Pandanus amaryllifolius ),Staphylococcus aureus Konsentrasi Hambat Minimum (KHM) dan Konsentrasi Bunuh Minimum (KBM)
\end{abstract}

\begin{abstract}
Pandanus amaryllifolius which is commonly used as a fragrance and food coloring has been so potential to have antibacterial activity. Staphylococcus aureus bacteria is the bacteria that can cause infection. The purpose of this study is to find out the activity of fragrant pandan leaves as antibacterial Staphylococcus aureus by knowing the Minimum Slave Concentration (KHM) and Minimum Kill Concentration (KBM) and to know what chemical compounds are contained in fragrant pandan leaves. Fragrant pandan leaf ethanol extract is obtained through the maseration method using $70 \%$ alcohol solvent. This research is an experimental study by using post test only control group design and applying dilusion method. The results suggest that the value of KHM at a concentration of $40 \%$ has been able to inhibit the growth of staphylococcus aureus bacteria. The Minimum Kill Concentration (KBM) of fragrant pandan leaf extract in the scented staphyloccocus aureus bacteria cannot yet be determined in value because at the highest concentration of $60 \%$ there is still an average colony growth of 27 colonies.
\end{abstract}

Keywords: Fragrant Pandanus Leaf (Pandanus amaryllifolius), Staphylococcus aureus Minimum Slave Concentration (KHM) and Minimum Kill Concentration (KBM) 


\section{PENDAHULUAN}

Penggunaan tumbuhan sebagai obat tradisional juga semakin banyak diminati oleh masyarakat karena telah terbukti bahwa obat yang berasal dari tumbuhan lebih menyehatkan dan tanpa menimbulkan adanya efek samping jika dibandingkan dengan obat-obatan yang berasal dari bahan kimia (Lestari, 2016).

Pandan wangi, latinnya yaitu Pandanus amaryllifolius, lazim digunakan sebagai pewangi dan pewarna makanan ternyata berpotensi memiliki aktivitas antibakteri. Bagian daun pada tanaman pandan wangi memiliki manfaat yaitu sebagai bahan tambahan makanan. Secara khusus, daun ini digunakan untuk memberikan warna hijau serta aroma untuk makanan. Aroma yang muncul dikarenakan ada senyawa turunan asam amino fenil alanin, yaitu 2-asetil1-pirrolin (Faras et al., 2014). Selain itu, pandan wangi juga memiliki beberapa aktivitas farmakologi berdasarkan pelarut ekstraknya, diantaranya sebagai antibakteri, antidiabetik, antikanker, dan antioksidan. Pelarut yang digunakan yaitu etanol dan etil asetat, air, etanol dan metanol, serta air dan methanol (Prameswari dan Widjanarko, 2014).

Di masa sekarang, bahan sintetis telah digunakan untuk mengawetkan makanan lebih tinggi daripada bahanbahan alami. Hal ini harus diatasi dengan mengembangkan bahan-bahan alami tersebut sebagai pengawet. Salah satunya mengurangi pertumbuhan bakteri indikator keamanan makanan yaitu Staphylococcus aureus (Faras et al., 2014).

Staphylococcus aureus dapat menyebabkan bermacam -macam infeksi seperti jerawat, dan Meningitis Osteomeolitis Pneomenia pada manusia, untuk mencegah hal ini terjadi maka sangat penting melakukan pengobatan infeksi dengan cara memberi obat antimikroba dan antibiotik yang tepat guna mengurangi infeksi Staphylococcus aureus. Dalam mengatasi infeksi bakteri, sering digunakan antibiotik yang masih banyak diresepkan dalam beberapa dekade sebagai solusi dalam menangani infeksi. (Jawetz, Melnick dan Adelberg’s. 2014). Penggunaan golongan antibiotik memiliki efek samping yang tidak diinginkan salah satunya yaitu menimbulkan resistensi jika penggunaannya tidak tepat (Candrasari dkk., 2012)

Berdasarkan hal tersebut, maka dicari alternatif lain dalam mengobati infeksi yaitu dengan menggunakan bahan bahan dari alam, salah satunya dengan 
meneliti tanaman tertentu yang diduga mengandung aktifitas antibakteri.

\section{METODE PENELITIAN}

\section{Alat}

Alat yang digunakan dalam penelitian ini meliputi alat-alat gelas laboratorium, timbangan digital, blender, batang pengaduk, vacum rotary evaporator, tabung steril, autoklaf, inkubator, lemari pendingin, tabung reaksi, gelas erlenmeyer, kawat ose, pipet tetes, cawan petri, pinset, laminar airflow, swab kapas, mikropipet, sarung tangan, lampu spiritus, gelas ukur, gelas kimia, kertas label, dan penggaris.

\section{Bahan}

Bahan-bahan yang digunakan dalam penelitian ini meliputi ekstrak daun pandan wangi (Pandanus amaryllifolius), nutrien agar (NA), nutrient broth (NB) etanol $70 \%, \quad \mathrm{Naoh}, \mathrm{Fecl}_{3} \quad 1 \%, \mathrm{Hcl}$, Pereaksi pb (III), antibiotik amoxicillin dan Aquadest.

\section{Persiapan bahan}

Dimulai dengan persiapan simplisia daun pandan wangi

(Pandanus amaryllifolius) yang masih segar yang diperoleh dari talang keramat kota Palembang diambil sebanyak $1 \mathrm{~kg}$ dicuci bersih, dan dipotong kecil-kecil, lalu dikeringkan dengan cara diangin-anginkan diudara terbuka (terlindungi dari sinar matahari). Proses pengeringan dilakukan kurang lebih 5 hari sampai daun pandan wangi kering dan mudah dihan curkan /diremukkan, kemudian simplisia diblender hingga halus untuk memperbesar luar permukaan partikel agar kontak antara zat dan larutan penyari lebih besar. Kemudian lakukan penimbangan kembali. Simplisia tadi selanjutnya diblender. Serbuk simplisia dimasukan kedalam kantong plastik dan disimpan ditempat yang jauh dari jangkauan sinar matahari.

\section{Pembuatan ekstrak etanol daun Pandan Wangi}

Sampel yang diekstrak ditimbang sebanyak 500 gram, kemudian direndam menggunakan etanol $70 \%$ sebanyak $\pm 3 \mathrm{~L}$ yang ditempatkan pada maserator sampai serbuk terendam semua, setelah itu sampel didiamkan kurang lebih 3 hari dengan sesekali diaduk, selanjutnya sampel disaring menggunakan kertas saring. Residu yang tertinggal ditambah lagi dengan etanol $70 \%$ sebanyak $1 \mathrm{~L}$ dan diberikan perlakuan yang sama diulang lagi sampai didapatkan ekstrak cair yang kedua. Selanjutnya semua ektrak cair tadi pertama dan kedua didapatkan dikumpulkan menjadi satu untuk dievaporasi sampai agak kental.Setelah agak kental,diuapkan diatas waterbath suhu $40^{\circ} \mathrm{c}$ untuk mendapatkan ekstrak yang lebih pekat. 
Randeman $=$

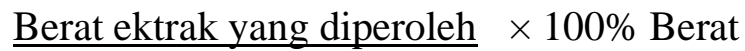
simplisia awal

\section{Uji fitokimia senyawa aktif pada ekstrak etanol daun pandan wangi}

a).Identikasi senyawa flavonoid

Ekstrak diambil 0.10 gram dan ditambahkan $5 \mathrm{ml}$ aquadest dan didihkan selama 5 menit kemudian disaring. Filtrat ditambahkan $1 \mathrm{ml} \mathrm{HCl}$ pekat dan sedikit serbuk Mg, lalu dikocok dan jika mengandung flavonoid maka akan menimbulkan warna merah, kuning atau jingga (Harbone, 2006).

b).Uji polifenol

Ekstrak diambil 0,10 gram, ditambahkan $5 \mathrm{ml}$ aquadest dan didihkan selama 5 menit. Kemudian disaring sehingga mendapatkan filtrat. Filtrat yang didapatlkan ditambahkan FeCl1\% sebanyak 5 tetes dan diamati perubahan warna yang terjadi. Adanya senyawa polifenol ditunjukkan dengan perubahan warna menjadi hijau biru hingga hitam

c).Identifikasi senyawa alkaloid

Ekstrak diambil 0,5gram dan ditambahkan $20 \mathrm{ml}$ HCL 2N. Kemudian dipanaskan diatas penangas air selama2 menit, setelah itu didinginkan dan disaring. Filtrat tersebut dibagi menjadi 2 untuk mereaksikan pengujian alkaloid dengan diteteskan pereaksi Mayer dan Dragendroff. Adanya senyawa alkaloid ditandai dengan adanya endapan

d).Identifikasi senyawa tannin

Sebanyak $1 \mathrm{ml}$ ekstrak daun pandan dimasukkan dalam tabung reaksi ditambahkan 4 tetes larutan $\mathrm{Fecl}_{3}$. Adanya senyawa tanin ditunjukkan perubahan warna hitam.

\section{Uji Aktivitas Antibakteri Dengan Metode Dilusi}

Metode dilusi cair dilakukan dengan meyiapkan beberapa tabung reaksi yang sudah steril,aquadest sebagai kontrol negatif, amoxicillin sebagai kontrol positif. Tabung reaksi disiapkan sebanyak 6 buah dan diberi -label nomor dari 1-6, kemudian tiap-tiap tabung diisi dengan $6 \mathrm{ml}$ Medium Brain Heart Infusion Broth (NB). Selanjutnya untuk tabung 1-4 ditambahkan 3 ml ekstrak mulai dari konsentrasi $20 \%, 40,60 \%$ lalu tambah $1 \mathrm{ml}$ suspensi bakteri uji, sehingga total masing-masing larutan pada tabung adalah $10 \mathrm{ml}$ kemudian semua tabung di vortex. Selanjutnya diinkubasi dalan inkubator pada suhu $37^{\circ} \mathrm{C}$ selama 24 jam. Diamati kekeruhan tabung 1-3 dan dibandingkan dengan kontrol positif (Amoxicillin) dan pelarut sebagai kontrol negatif. Konsentrasi paling rendah dan menunjukkan kejernihan adalah KHM. 
Hasil uji Kosentrasi hambat minimum (KHM) kemudian dilakukan uji lanjutan untuk mengetahui Konsentrasi Bunuh Minimum (KBM) dengan menggunakan konsetrasi ekstrak daun pandan wangi dari hasil uji KHM yaitu pada konsentrasi $20 \%$, 40\%, dan 60\%, dengan cara mengambil $0,1 \mathrm{ml}$ dari setiap larutan konsetrasi lalu dilakukan penggoresan pada media padat Nuterient Agar (NA). Kemudian diinkubasikan selama 24 jam pada suhu $37^{\circ} \mathrm{C}$, yang ditandai dengan ada atau tidaknya pertumbuhan koloni bakteri pada media tersebut yaitu menghitung jumlah koloni bakteri menggunakan colony counter, dengan melihat jumlah koloni dari setiap perlakuan serial konsentrasi ekstrak.

\section{HASIL PENELITIAN}

\section{Tabel 4.1 Hasil Pengamatan} Organoleptis

\begin{tabular}{|l|l|l|}
\hline 1 & Bentuk & Kental \\
\hline 2 & Warna & Hijau pekat \\
\hline 3. & Bau & $\begin{array}{l}\text { Khas Daun } \\
\text { Pandan }\end{array}$ \\
\hline
\end{tabular}

Berdasarkan table 4.1 , menun jukkan bahwa sifat organoleptis dari daun pandan wangi (Pandanus amaryllifolius) adalah berwarna hijau pekat dengan bau khas daun pandan. Menurut DEPKES RI (2000), Parameter organoleptik ekstrak bertujuan memberikan pengenalan awal terhadap simplisia dan ekstrak menggunakan panca indera dengan mendeskripsikan bentuk, warna, bau dan rasa.

\subsection{Hasil Skrining fitokimia}

\begin{tabular}{|l|l|l|l|l|}
\hline $\begin{array}{l}\mathrm{N} \\
\mathrm{o}\end{array}$ & $\begin{array}{l}\text { Kan } \\
\text { dung } \\
\text { an }\end{array}$ & $\begin{array}{l}\text { Pereaks } \\
\mathrm{i}\end{array}$ & $\begin{array}{l}\text { Penga } \\
\text { matan }\end{array}$ & Hasil \\
\hline 1 & $\begin{array}{l}\text { Alka } \\
\text { loid }\end{array}$ & $\begin{array}{l}\text { Dragen } \\
\text { drof,ma } \\
\text { yer,bou } \\
\text { ncharda } \\
\mathrm{t}\end{array}$ & $\begin{array}{l}\text { Dragendof } \\
\text { (endapan } \\
\text { orange) } \\
\text { mayer } \\
\text { (endapan } \\
\text { orange) }\end{array}$ & Positif \\
\hline 2 & $\begin{array}{l}\text { Flav } \\
\text { anoi } \\
\mathrm{d}\end{array}$ & $\begin{array}{l}\text { Hcl } \\
\text { pekat } \\
\text { dan } \mathrm{Mg}\end{array}$ & jingga & Positif \\
\hline 3 & $\begin{array}{l}\text { Tann } \\
\text { in } \\
\text { dan } \\
\text { Polif } \\
\text { enol }\end{array}$ & Fec $l_{3}$ & hitam & Positif \\
\hline
\end{tabular}

Berdasarkan tabel 4.2 menun jukkan daun pandan wangi positif mengandung senyawa metabolit alkaloid flavanoid, tannin dan polifenol. Menurut DEPKES RI (2000), Uji kandungan kimia bertujuan untuk memberikan gambaran awal komposisi kandungan kimia.

\section{Hasil Uji Penentuan Konsentrasi Hambat Minimum Dengan Metode Dilusi Cair}

Tabel 4.3 Hasil Kadar Hambat Minimum (KHM)

\begin{tabular}{|l|l|}
\hline Konsentrasi & Kekeruhan \\
\hline Konsentrasi $20 \%$ & -- \\
\hline Konsentrasi $40 \%$ & - \\
\hline Konsentrasi 60\% & ++ \\
\hline Kontrol positif & +++ \\
\hline Kontrol Negatif & - \\
\hline
\end{tabular}


Keterangan hasil ;

$$
\begin{array}{cll}
\text { Kontrol Positif } & : \text { Amoxicillin } \\
\text { Kontrol Negatif } & : \text { Aquadest Steril } \\
+ & : \text { Tidak ada } \\
& \text { pertumbuhan } \\
& \text { bakteri (jernih) } \\
- & : \text { Ada Pertumbuhan } \\
& \text { Bakteri }
\end{array}
$$

Berdasarkan tabel 4.3 diatas ekstrak etanol daun pandan wangi (Pandanus amaryfolius) pada konsentrasi $20 \%$ tidak dapat menghambat bakteri Staphylococus aureus karena ditandai dengan tingkat kekeruhan yang lebih tinggi.Sedangkan pada konsentrasi $40 \%$ sudah mulai menghambat bakteri Staphylococus aureus karena sudah menandakan kejernihan.

\section{4 Hasil Uji Penentuan Konsentrasi Bunuh Minimum (KBM) dengan Metode Dilusi Padat}

Hasil uji aktivitas daya bunuh ekstrak etanol daun pandan wangi dengan melihat pertumbuhan bakteri dapat dilihat dengan colony counter dapat dilihat pada tabel di bawah ini.

\section{Tabel 4.4 hasil Perhitungan koloni}

\begin{tabular}{|l|l|l|l|l|}
\hline \multirow{2}{*}{ Konsentrasi } & $\begin{array}{l}\text { Jum } \\
\text { lah }\end{array}$ & \multicolumn{3}{|l|}{$\begin{array}{l}\text { Ko } \\
\text { lon }\end{array}$} \\
\cline { 2 - 5 } & P1 & P2 & P3 & \multicolumn{1}{|c|}{} \\
\hline $20 \%$ & 74 & 67 & 56 & 65,6 \\
\hline $40 \%$ & 40 & 36 & 32 & 36 \\
\hline $60 \%$ & 29 & 27 & 25 & 27 \\
\hline $\begin{array}{l}\text { Kontrol + } \\
\text { Amoxxilin }\end{array}$ & 28 & 20 & 19 & 22,3 \\
\hline $\begin{array}{l}\text { Kontrol } \\
\text { Aquadest }\end{array}$ & 107 & $\begin{array}{l}10 \\
8\end{array}$ & $\begin{array}{l}10 \\
5\end{array}$ & $\begin{array}{l}106 \\
6\end{array}$ \\
\hline
\end{tabular}

Berdasarkan tabel 4.4, hasil penelitian uji konsentrasi bunuh minimum (KBM) yang telah dilakukan, ekstrak etanol daun pandan wangi terhadap bakteri staphylococus aureus pada konsentrasi $20 \%, 40 \%, 60 \%$, mulai menunjukan adanya pengurangan jumlah pertumbuhan koloni bakteri. Tiap konsentrasi dilakukan 3 kali pengulangan dan menunjukan jumlah pertumbuhan koloni yang berbeda.

Setelah itu dilanjutkan dengan uji satu arah anova untuk mengetahui perbedaan daya antibakteri antar kelompok perlakuan terhadap bakteri staphylococcus aureus, di dapat hasil sebagai berikut:

Tabel 4.5. Anova satu arah uji aktivitas anti bakteri ekstrak etanol daun panda wangi (pandanus amaryfolius)

Terhadap staphylococcus aureus

\begin{tabular}{|l|l|l|l|l|l|}
\hline & $\begin{array}{l}\text { Jumlah } \\
\text { kuadrat }\end{array}$ & $\begin{array}{l}\text { Der } \\
\text { ajat } \\
\text { Be } \\
\text { bas }\end{array}$ & $\begin{array}{l}\text { Rata } \\
\text { rata } \\
\text { kuadrat }\end{array}$ & F hitung & $\begin{array}{l}\text { F } \\
\text { tabel }\end{array}$ \\
\hline $\begin{array}{l}\text { Antar } \\
\text { group }\end{array}$ & 14805.733 & 4 & $\begin{array}{l}3701.4 \\
33\end{array}$ & 143.466 & .000 \\
\hline $\begin{array}{l}\text { Dlm } \\
\text { group }\end{array}$ & 258.000 & 10 & 25.800 & & \\
\hline Total & 15063.733 & 14 & & & \\
\hline
\end{tabular}

Berdasarkan data diatas hasil uji satu arah anova menunjukan bahwa nilai $\mathrm{p}=.000$ $(p<0.05)$ yang berarti terdapat perbedaan yang bermakna atau ekstrak etanol daun pandan wangi (Pandanus amaryfolius) berpengaruh nyata dalam menghambat pertumbuhan bakteri staphyloccocus aureus. 


\section{PEMBAHASAN}

Penelitian ini dilakukan bertujuan untuk mengetahui aktivitas daun pandan wangi sebagai antibakteri Staphylococcus aureus. Penelitian ini menggunakan simplisia daun pandan wangi (Pandanus amaryllifolius) yang terlebih

Pengeringan simplisia ada dua metode yaitu pengeringan alamiah dan pengeringan buatan. Pengeringan alamiah yaitu dengan cara mengeringkan simplisia dibawah sinar matahari atau tanpa sinar matahari dengan cara di anginanginkan. Pengeringan buatan adalah pengeringan dengan menggunakan suatu alat pengeringan, suhu kelembaban, tekanan dan aliran udara dapat diatur (Gunawan D.S.M 2004). Susut pengeringan merupakan salah satu parameter non spesifik yang bertujuan untuk memberikan batasan maksimal (rentang) tentang besarnya senyawa yang hilang pada proses pengeringan. Parameter susut pengeringan pada dasarnya adalah pengukuran sisa zat setelah pengeringan pada temperatur $105^{\circ} \mathrm{C}$ sampai berat konstan, yang dinyatakan sebagai nilai persen (Depkes RI., 2000). Kadar air yang diperoleh pada simplisia dan ekstrak masing masing sesuai dengan syarat mutu yaitu $\leq 10 \%$. Ekstrak kental memilki kadarair antara 5 - 30\% (Voight, 1994). dahulu dilakukan pengeringan, bertujuan agar simplisia menjadi awet. simplisia daun pandan wangi (Pandanus amaryllifolius) yang terlebih dahulu dilakukan pengeringan, bertujuan agar simplisia menjadi awet.

Penentuan kadar air juga terkait dengan kemurnian ekstrak. Kadar air yang terlalu tinggi (> 10\%) menyebabkan tumbuhnya mikroba yang akan menurunkan stabilitas ekstrak (Saifudin dkk., 2011).

Simplisia diserbukkan dengan tujuan untuk meningkatkan luas permukaan sehingga penyari akan lebih mudah menembus dinding sel dan zat aktif yang terdapat di dalam sel akan tersari (Indraswari, A. 2008) Metode maserasi digunakan untuk mengekstrak zat aktif dari simplisia daun pandan wangi (Pandanus amaryllifolius) dengan menggunakan etanol $70 \%$ sebagai penyari. metode maserasi baik digunakan untuk menarik zat berkhasiat yang tahan pemanasan maupun tidak tahan pemanasan, serta sederhana dalam pengerjaan dan alat-alat yang digunakan (Djamal, 2012). Pelarut yang digunakan untuk maserasi adalah etanol. Pelarut etanol digunakan karena bersifat universal yang dapat menarik zat polar maupun non polar, digunakan secara luas dalam bidang farmasi, tidak bersifat racun 
dengan titik didih yang lebih rendah dari air sehingga meminimalisir terjadinya kerusakan pada zat-zat yang tidak tahan panas

(Djamal, 2012). Menurut Yulaikha, Y.U. (2009) etanol lebih selektif, kuman sulit tumbuh dalam etanol $>20 \%$, tidak beracun, netral dan absorsinya baik.

\section{Berdasarkan hasil skrining}

fitokimia terhadap ekstrak daun pandan wangi, metabolit yang didapat adalah positif mengandung senyawa alkaloid flavanoid, tannin dan polifenol. Menurut DEPKES RI (2000) uji kandungan kimia bertujuan untuk memberikan gambaran awal komposisi kandungan kimia. Metabolit sekunder merupakan senyawa metabolit yang tidak esensial bagi pertumbuhan organisme dan ditemukan dalam bentuk yang berbeda-beda antara spesies yang satu dan lainnya. Setiap organisme biasanya menghasilkan senyawa metabolit sekunder yang berbeda-beda, bahkan satu jenis senyawa metabolit sekunder hanya ditemukan pada satu spesies dalam suatu kingdom (Gunawan, D.S.M. 2004).

Berdasarkan Hasil Uji Penentuan Konsentrasi Bunuh Minimum (KBM) yang telah dilakukan ekstrak etanol daun pandan wangi terhadap bakteri staphylococus aureus pada konsentrasi 20\%,40\%,60\%, yang menunjukan adanya pengurangan jumlah pertumbuhan koloni bakteri. Koloni bakteri pada kosentrasi $20 \%$ berjumlah 65,6 koloni, yang semakin menurun pada kosentrasi ekstrak $40 \%$ dan $60 \%$ yaitu berjumlah 36 koloni dan 27 koloni.. Berdasarkan hasil uji Anova satu arah uji aktivitas anti bakteri ekstrak etanol daun pandan wangi (pandanus amaryfolius) terhadap staphylococcus aureus menunjukan bahwa nilai $\mathrm{p}=.000 \quad(\mathrm{p}<0.05)$ yang berarti terdapat perbedaan bermakna terdapat hambatan pertumbuhan bakteri staphyloccocus aureus.

Hal tersebut sesuai dengan referensi yang menyatakan semakin tinggi konsentrasi ekstrak, semakin banyak pula kandungan senyawa aktif berdifusi ke dalam bakteri yang dapat membunuh bakteri tersebut (Pelczar, 1998). Penelitian yang telah dilakukan Dumoal dkk, (2010) membuktikan bahwa ekstrak daun pandan dapat menghambat pertumbuhan bakteri Staphylococcus aureus pada konsentrasi $40 \%$ dengan daya hambat sebesar $13 \mathrm{~mm}$. Selain itu Mardiyaningsih, A., \& Aini, R. (2014), juga melaporkan bahwa ekstrak etil asetat daun pandan berpotensi menghambat pertumbuhan bakteri Staphylococcus aureus sebesar $15,7 \mathrm{~mm}$ dan Escherichia coli sebesar $17,7 \mathrm{~mm}$ dengan loading dose $5 \mathrm{mg} /$ disc. .

Adanya perbedaan diameter hambatan dapat disebabkan kandungan 
kimia dalam ekstrak etanol daun pandan wangi yaitu berupa senyawa alkaloid flavanoid, tannin dan polifenol. Mekanisme kerja flavonoid sebagai antibakteri yaitu dengan cara menghambat fungsi membran sel dalam membentuk senyawa kompleks dengan protein ekstraseluler dan terlarut sehingga merusak membran sel bakteri yang diikuti keluarnya senyawa intraseluler (Nuria, 2009). Monalisa dkk (2011) , menyatakan mekanisme senyawa yang berkhasiat sebagai antibakteri yaitu senyawa flavanoid memiliki aktivitas antibakteri dengan cara mengikat asam amino nukleofilik pada protein dan inaktivitasi enzim .

Alkaloid sebagai antibakteri bekerja menggangu komponen penyusun peptidoglikan pada sel bakteri yang menyebabkan tidak terbentuknya lapisan dinding sel bakteri secara utuh sehinggan terjadinya kematian sel pada bakteri (Darsana 2012). Senyawa alkaloid memiliki kemampuan sebagai anti bakteri. Mekanisme Penghambatan bakteri oleh senyawa ini dengan menggangu komponen penyusun peptidoglika pada sel bakteri sehingga lapisan dinding sel tidak terbentuk secara utuh dan menyebabkan kematian sel tersebut (Monalisa dkk,2011).

Tannin adalah salah satu senyawa metabolit yang ditemukan dalam uji antibakteri ekstrak daun pandan wangi terhadap Staphilococcus aureus . Menurut Monalisa (2011), Senyawa tannin bekerja dengan cara menghambat dinding protein sehingga pembentukan dinding sel bakteri terhambat.

\section{KESIMPULAN}

Berdasarkan hasil penelitian yang telah dilakukan dapat disimpulkan sebagai berikut :

1. Ekstrak etanol pandan wangi (Pandanus amaryifolius) mengandung metabolit yaitu senyawa alkaloid, flavonoid, tannin dan polifenol

2. Konsentrasi Bunuh Minimum (KBM) ekstrak daun pandan wangi (Pandanus amaryifolius) pada bakteri staphyloccocus aureus menunjukkan adanya pengurangan jumlah pertumbuhan koloni bakteri, yaitu pada kosentrasi $20 \%$ berjumlah 65,6 koloni, yang semakin menurun pada kosentrasi ekstrak $40 \quad \%$ dan $60 \%$ yaitu berjumlah 36 koloni dan 27 koloni, dengan nilai KBM mencapai jumlah nol (0) koloni belum diperoleh.

3. Hasil uji Anova satu arah uji aktivitas antibakteri ekstrak etanol daun pandan wangi (Pandanus amaryfolius) terhadap 


$\begin{array}{lr}\text { staphylococcus } & \text { aureus } \\ \text { menunjukan bahwa nilai } \mathrm{p}=.000 \\ (\mathrm{p}<0.05) \text { yang berarti terdapat } \\ \text { perbedaan bermakna terdapat } \\ \text { hambatan pertumbuhan bakteri } \\ \text { staphyloccocus aureus. }\end{array}$

\section{SARAN}

Penelitian selanjutnya disarankan untuk menggunakan kosentrasi ekstrak daun pandan wangi (Pandanus amaryfolius) lanjutan yaitu yang dimulai dari kosentrasi $65 \%$ serta menggunakan variasi metodelogi dalam pengujian aktivitas antimikroba dari ekstrak etanol daun pandan wangi (Pandanus amaryifolius).

\section{DAFTAR PUSTAKA}

Candrasari, A., dkk., 2012 ,Uji Daya Antimikroba Ekstrak Etanol Daun Sirih Merah (Piper Crocatum Ruiz \& Pav.) Terhadap Pertumbuhan Staphylococcus aureus, Eschericia coli dan Candida albicans Secara In Vitro, Biomedia, 4(1), pp. 9-15.

\section{Darsana, I.G.O., $\quad$ Besung, I.N.K., Mahatmi, H. 2012. Potensi daun binahong (Anredera cordifolia (Tenore) Steenis) dalam mengyhambat pertumbuhan bakteri Escherichia coli secara in vitro. Indonesia Medicus Veterinus, 1(3): 337-351.}

Departemen Kesehatan Republik
Indonesia. Jakarta. Departemen Kesehatan, 2000. Inventaris Tanaman Obat Indonesia.

Departemen Kesehatan Republik Indonesia. 2000. Parameter Standar Umum Ekstrak Tumbuhan Obat. Jakarta, Indonesia.

Djamal, R. (2012). Kimia Bahan Alam: Prinsip-Prinsip dasar isolasi dan identifikas (3rded). Padang: Universitas Baiturahman.

Dumoal,O.S.R, Alaras,LB., Dahilan, K.G., Sarah, Dapadua, A.A., Pulmones, C.J.G. 2010. In vitro activity of pandan (Pandanus maryllifolius) leaves crude ekstrak against selected bacterial isolated. National peer reviewed jurnal, 4.20123981.doi:

10.7719/jpair.v4i1.103

Faras, A.F., Wadkar, S.S., and Ghosh, J.S., 2014, Effect of Leaf

Extract of Pandanus amaryllifolius Roxb on Growth of Escherichia coli and Micrococcus, Staphylococcus aureus, International Food Research Journal 21(1):421-423

Gunawan, D . S M. 2004. Ilmu Obat Alam (Farmakognosi) Jilid 1. Jakarta: Penebar Swadaya Grup; p. 140.

Harbone 2006. Metode Fitokimia penuntun cara modern menganalisis tumbuhan (alih Bahasa kosasih padmawinata $\&$ iwang soedirogi). Penerbit ITB: Bandung.

Indraswari, Arista. 2008. Optimasi p embuatan ekstrak daun dewandaru (Eugenia uniflora 1.) Menggunakan metode maserasi dengan parameter kadar total senyawa fenolik dan flavonoid. Skripsi. Fakultas Farmasi Muhamadiyah, Surakarta. 
Jawetz, Melnick dan Adelberg's. 2014.

Mikrobiologi Kedokteran . Edisi 25, cetakan 2013. Alih Bahasa: Aryanto Widhi Nugroho, dkk. Jakarta: Penerbit Buku Kedokteran EGC.

Lestari. E. 2016. Kajian Etnobotani Tumbuhan Mahar (Klein Hospital L.) Di Batu Tangga Kecamatan Batang Timur. Jurnal Whana-Bio. Volume XVI.

Mardiyaningsih, A., \& Aini, R. 2014.

Pengembangan potensi ekstrak daun pandan wangi (Pandanus amaryllifolius Roxb) sebagai agen antibakteri. Pharmaciana, 4: 185192.

Monalisa D., Handayani,T., Sukmawati D. 2011. Uji Daya Antibakteri Daun tapak Liman (Elepanthus scaber L) terhadap Staphilococcos aureus dan Salmonella typhi. Jurnal BIOMA, 9 (2) , 13-20.

Nuria, M.C., Faizatun, A., Sumantri.2009. Uji antivitas antibakteri ekstrak etanol daun jarak pagar (Jatropha curcas L) terhadap bakteri Staphylococcus aureus ATCC 25923, E,coli ATCC 25922,dan Salmonella typhi ATCC 1408. Mediagro, 5(2): 26-37.

Pelczar, J.M., \& Scan, E.C.S. 1988.

Dasar-dasar mikrobiologi jilid 2. Jakarta; UI-press

Prameswari, O. M., dan Widjanarko, S. B. 2014. Uji Efek Ekstrak Air Daun Pandan Wangi
Terhadap Penurunan Kadar Glukosa Darah Dan Histopatologi Tikus Diabetes Mellitus, Jurnal Pangan dan Agroindustri Vol.2 No.2 p.1627

Saifuddin, A. Rahayu. Yuda Irwan. 2011.

Standarisasi Bahan Obat Alam.Graha Ilmu. Yogyajarta. Hal 1-22.

Voight, R.. 1994. Buku Pengantar Teknologi Farmasi, 572-574, diterjemahkan oleh Soedani, N., Edisi V, Yogyakarta, Universitas Gadjah Mada Press.

Yulaikha, Y. U. 2009. Pengaruh Kadar Bahan Pengikat Polivinil Pirolidon Terhadap Sifat Fisik Tablet Effervescent Campuran Ekstrak Daun Salam (Syzigium plyanthum Wight) dan Kumis Kucing (Orthosiphon aristatus Blume. Miq). Skripsi. Fakultas Farmasi Muhamadiyah, Surakarta. 